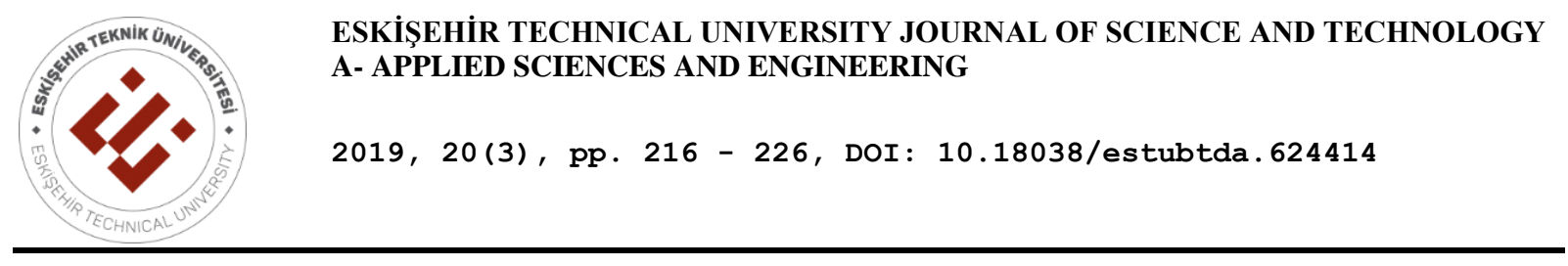

\title{
VIBRATIONAL SPECTROSCOPIC AND THERMAL INVESTIGATIONS OF THE CYANO- BRIDGED POLYMERIC COMPLEXES WITH 3-AMINOMETHYLPYRIDINE
}

\author{
Dursun KARAAĞAC
}

Ulubatlı Hasan Anatolian High School, TR-16320, Bursa, Turkey

\begin{abstract}
New cyano-bridged polymeric complexes formulated as $\left[\mathrm{Co}\left(\mathrm{H}_{2} \mathrm{O}\right)(\operatorname{ampy}) \mathrm{Ni}(\mathrm{CN})_{4}\right] \cdot \mathrm{H}_{2} \mathrm{O}$ and $\left[\mathrm{Ni}(\operatorname{ampy})_{2} \mathrm{Ni}(\mathrm{CN})_{4}\right] \cdot \mathrm{H}_{2} \mathrm{O}(\operatorname{ampy}$ = 3-aminomethylpyridine: abbreviated henceforth as Co-Ni-ampy and Ni-Ni-ampy) have been obtained in powder form and characterized by vibrational (infrared and Raman) spectroscopy, thermal and elemental analyses. In previous study, structure of complex $\left[\mathrm{Cd}\left(\mathrm{NH}_{3}\right)(\text { ampy }) \mathrm{Ni}(\mathrm{CN})_{4}\right]_{\mathrm{n}}(\mathrm{Cd}-\mathrm{Ni}$-ampy) was determined by single crystal X-ray diffraction methods. In this complex, the coordination environment of the $\mathrm{Cd}(\mathrm{II})$ ions are distorted octahedral geometry, whereas around the $\mathrm{Ni}$ (II) center is pyramidal. The spectral features suggest that Cd-Ni-ampy with Co-Ni-ampy are similar to each other and the ampy ligand is coordinated to metal ions as bidentate ligand. In addition, complex Ni-Ni-ampy is similar in structure to the Hofmann type complexes and its structure consists of polymeric layers of $\left|\mathrm{Ni}-\mathrm{Ni}(\mathrm{CN})_{4}\right|_{\infty}$ with the ampy ligand bounded to the nickel(II) atom. Thermal stabilities and decomposition products of the complexes were investigated using TG, DTG and DTA curves in the temperature range of $30-700{ }^{\circ} \mathrm{C}$ in the static air atmosphere.
\end{abstract}

Keywords: Vibrational spectra, Tetracyanonickelate(II), 3-aminomethylpyridine, Cyano-bridged complexes, Pyramidal

\section{INTRODUCTION}

Cyano-bridged polymeric complexes containing cyanometallate building blocks such as $\left[\mathrm{Ni}(\mathrm{CN})_{4}\right]^{2-}$, $\left[\mathrm{Pd}(\mathrm{CN})_{4}\right]^{2-},\left[\mathrm{Pt}(\mathrm{CN})_{4}\right]^{2-}$ and $\left[\mathrm{Au}(\mathrm{CN})_{4}\right]^{-}$have been intensely explored owing to their potential application as hosts for smaller molecules, molecular sieves, chemical sensors and ion exchangers [14]. In general, cyanometallate building blocks, $\left[\mathrm{M}(\mathrm{CN})_{\mathrm{x}}\right]^{\mathrm{n}-}$ have been used to create one- (1D), two-(2D) and three-(3D) dimensional structures [5-8] due to the cyanide ion can coordinate as monodentate or bidentate ligand to different metal cations. Therefore, cyanometallates can easily form coordination polymers with transition-metal cations and the presence of cyanide can be readily determined with the $\mathrm{C} \equiv \mathrm{N}$ vibrational stretch in the infrared and Raman spectra $[9,10]$. Many researchers have focused on octahedral $\left[\mathrm{M}(\mathrm{CN})_{6}\right]^{\mathrm{n}-}$ but less have focused on square-planar $\left[\mathrm{M}(\mathrm{CN})_{4}\right]^{\mathrm{n-}}$ building blocks [11-13]. The square-planar building blocks are used extensively in the synthesis of Hofmann-type complexes. Hofmann-type complexes are given with the general formula $\left[\mathrm{M}(\mathrm{L})_{\mathrm{x}} \mathrm{M}^{\prime}(\mathrm{CN})_{4}\right]$ (where $\mathrm{x}=2$ or $1 ; \mathrm{M}$ (II) $=\mathrm{Co}, \mathrm{Ni}, \mathrm{Cu}, \mathrm{Zn}$ or $\mathrm{Cd} ; \mathrm{M}^{\prime}(\mathrm{II})=\mathrm{Ni}, \mathrm{Pd}$ or Pt) form 2- or 3-dimensional polymeric structures by metalligand-metal bridge connections [4]. In the literature, there are too many cyano-bridged polymeric complexes obtained using $\left[\mathrm{Ni}(\mathrm{CN})_{4}\right]^{2-}$ building unit [14-17].

In our previous study, we reported the preparation, vibrational (FT-IR and Raman) spectroscopic, thermal, and single-crystal X-ray diffraction studies of the cyano-bridged 3D heteronuclear polymeric complex with the formula $\left[\mathrm{Cd}\left(\mathrm{NH}_{3}\right)\left(\mu \text {-ampy) } \mathrm{Ni}(\mathrm{CN})_{4}\right]_{\mathrm{n}}\right.$, (ampy $=3$-aminomethylpyridine) [18]. The crystal structure of Cd-Ni-ampy is shown in Figure 1. In the crystal structure of Cd-Ni-ampy, $\mathrm{Ni}$ (II) ion is pyramidal by the four carbon atoms of cyano ligands and one nitrogen atom of the ampy ligand and this geometry is rare for tetracyanonickelate (II) ion in the literature. The $\mathrm{Cd}(\mathrm{II})$ ion is six coordinated by the six $\mathrm{N}$ atoms from one ammonia, one ampy and four cyano ligands. We have extended this study and prepared $\left[\mathrm{Co}\left(\mathrm{H}_{2} \mathrm{O}\right)(3 \mathrm{ampy}) \mathrm{Ni}(\mathrm{CN})_{4}\right] \cdot \mathrm{H}_{2} \mathrm{O}$ and $\left[\mathrm{Ni}(3 \mathrm{ampy})_{2} \mathrm{Ni}(\mathrm{CN})_{4}\right] \cdot \mathrm{H}_{2} \mathrm{O}$ (ampy = 3aminomethylpyridine) complexes for the first time. Therefore, in the present article we describe the

*Corresponding Author: ddkaraagac@hotmail.com

Received: 08.08.2018 Published: 26.06.2019 
synthesis, vibrational study and thermal behavior of tetracyanonickelate(II) with the 3aminomethylpyridine.

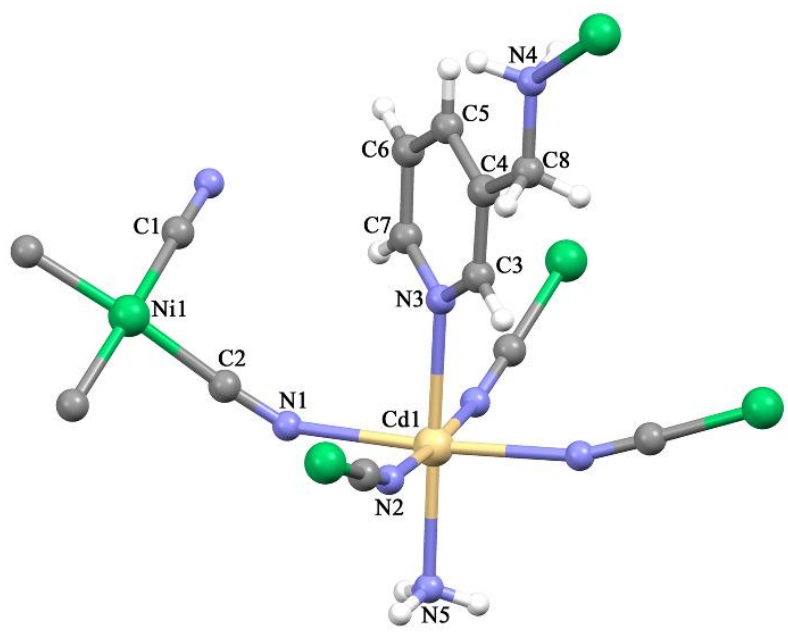

Figure 1. The asymmetric unit of Cd-Ni-ampy with the atom numbering scheme (The $\mathrm{NH}_{3}$ in the crystal structure of complex Cd-Ni-ampy is replaced by $\mathrm{H}_{2} \mathrm{O}$ ligand in complex Co-Ni-ampy) [18]

\section{EXPERIMENTAL}

\subsection{Materials}

Cobalt(II) chloride tetrahydrate $\left(\mathrm{CoCl}_{2} \cdot 4 \mathrm{H}_{2} \mathrm{O}, 98 \%\right)$, nickel(II) chloride hexahydrate $\left(\mathrm{NiCl}_{2} \cdot 6 \mathrm{H}_{2} \mathrm{O}\right.$, $97 \%)$, potassium cyanide $(\mathrm{KCN}, 96 \%)$ and 3 -aminomethylpyridine $\left(\mathrm{C}_{6} \mathrm{H}_{9} \mathrm{~N}_{2}, 97 \%\right)$ from commercial sources were used as received.

\subsection{Syntheses of the Complexes}

The $\mathrm{K}_{2}\left[\mathrm{Ni}(\mathrm{CN})_{4}\right] \cdot \mathrm{H}_{2} \mathrm{O}$ complex was synthesized according to literature [19]. $1 \mathrm{mmol}(0.259 \mathrm{~g})$ of $\mathrm{K}_{2}\left[\mathrm{Ni}(\mathrm{CN})_{4}\right] \cdot \mathrm{H}_{2} \mathrm{O}$ was dissolved in distilled water $(10 \mathrm{~mL})$ under stirring at room temperature, then $1 \mathrm{mmol}$ of the metal(II) chloride $\left(\mathrm{CoCl}_{2} \cdot 4 \mathrm{H}_{2} \mathrm{O}=0.202 \mathrm{~g}\right.$ or $\left.\mathrm{NiCl}_{2} \cdot 6 \mathrm{H}_{2} \mathrm{O}=0.238 \mathrm{~g}\right)$ prepared with distilled water $(10 \mathrm{~mL})$ was added to the dissolved $\mathrm{K}_{2}\left[\mathrm{Ni}(\mathrm{CN})_{4}\right] \cdot \mathrm{H}_{2} \mathrm{O}$ dropwise. The colors of $\mathrm{Co}\left[\mathrm{Ni}(\mathrm{CN})_{4}\right] \cdot \mathrm{H}_{2} \mathrm{O}$ and $\mathrm{Ni}\left[\mathrm{Ni}(\mathrm{CN})_{4}\right] \cdot \mathrm{H}_{2} \mathrm{O}$ are pink and pale blue, respectively. A mixture of $\left\{\mathrm{Co}\left[\mathrm{Ni}(\mathrm{CN})_{4}\right] \cdot \mathrm{H}_{2} \mathrm{O}=0.240 \mathrm{~g}, 1 \mathrm{mmol}\right.$ or $\left.\mathrm{Ni}\left[\mathrm{Ni}(\mathrm{CN})_{4}\right] \cdot \mathrm{H}_{2} \mathrm{O}=0.239 \mathrm{~g}, 1 \mathrm{mmol}\right\}$ in water $(10 \mathrm{~mL})$, ampy $(2 \mathrm{mmol}, 0.216 \mathrm{~g})$ dissolved in ethanol $(10 \mathrm{~mL})$ was stirred at $40^{\circ} \mathrm{C}$ for $4 \mathrm{~h}$ in a temperature-controlled bath. The obtained complexes were filtered and washed with pure water and ethanol, respectively and dried in air. The freshly prepared complexes were analyzed for $\mathrm{C}, \mathrm{H}$ and $\mathrm{N}$, and elemental analysis data of the complexes were given in Table 1 .

Table1. Elemental analysis data of the complexes

\begin{tabular}{|c|c|c|c|c|c|c|c|c|}
\hline \multirow[t]{3}{*}{ Complex } & \multirow{3}{*}{$\begin{array}{c}\text { Molecular } \\
\text { formula }\end{array}$} & \multirow{3}{*}{$\begin{array}{c}\mathrm{M}_{\mathrm{wt} .} \\
(\mathrm{g} / \mathrm{mol})\end{array}$} & \multicolumn{6}{|c|}{ Elemental analyses } \\
\hline & & & \multicolumn{2}{|c|}{$\mathrm{C} \%$} & \multicolumn{2}{|c|}{$\mathrm{H} \%$} & \multicolumn{2}{|c|}{ N\% } \\
\hline & & & Calc. & Found & Calc. & Found & Calc. & Found \\
\hline$\left[\mathrm{Co}\left(\mathrm{H}_{2} \mathrm{O}\right)(3 \mathrm{ampy}) \mathrm{Ni}(\mathrm{CN})_{4}\right] \cdot \mathrm{H}_{2} \mathrm{O}$ & $\mathrm{C}_{10} \mathrm{H}_{12} \mathrm{~N}_{6} \mathrm{O}_{2} \mathrm{NiCo}$ & 365.87 & 32.83 & 34.01 & 3.31 & 3.45 & 22.97 & 22.69 \\
\hline$\left[\mathrm{Ni}(3 \mathrm{ampy})_{2} \mathrm{Ni}(\mathrm{CN})_{4}\right] \cdot \mathrm{H}_{2} \mathrm{O}$ & $\mathrm{C}_{16} \mathrm{H}_{18} \mathrm{~N}_{8} \mathrm{ONi}_{2}$ & 437.74 & 42.17 & 42.69 & 3.98 & 4.05 & 24.59 & 25.26 \\
\hline
\end{tabular}

\subsection{Measurements}

Elemental analyses were carried out on a LECO, CHNS-932 analyzer for C, $\mathrm{H}$ and $\mathrm{N}$ at the Middle East Technical University Central Laboratory in Ankara, Turkey. The infrared spectra of discs (KBr) of fresh 
samples were recorded in the range of $4000-400 \mathrm{~cm}^{-1}$ with a $2 \mathrm{~cm}^{-1}$ spectral resolution by using a Perkin Elmer 100 FT-IR spectrometer, which was calibrated by means of polystyrene and $\mathrm{CO}_{2}$ bands. Raman spectrum of the synthesized complexes were recorded between 4000 and $250 \quad \mathrm{~cm}^{-1}$ on a Bruker Senterra Dispersive Raman apparatus using $785 \mathrm{~nm}$ laser excitation. A Perkin Elmer Diamond TG/DTA thermal analyzer was used to record simultaneous TG, DTG and DTA curves of the complexes in a static air atmosphere at a heating rate of $10 \mathrm{~K} \mathrm{~min}^{-1}$ in the temperature range $30-700{ }^{\circ} \mathrm{C}$ using platinum crucibles.

\section{RESULTS AND DISCUSSION}

\subsection{Vibrational Spectra}

\subsubsection{3-Aminomethylpyridine vibrations}

The infrared spectra of the ampy, the infrared and Raman spectra of Co-Ni-ampy and Ni-Ni-ampy are illustrated in Figures 2-4, respectively. The vibrational assignments of the ampy ligand observed in the spectra of the complexes were made according to the 2-aminomethylpyridine ligand [20-22] and were given in Table 2, together with the wavenumbers of the free ampy molecule in the liquid phase. So far, there has been no comprehensive vibrational study of 3-aminomethylpyridine molecule. However, the infrared spectral data of 2-aminomethylpyridine [22] have been reported. The proposed assignment of the infrared bands of the ampy in the complexes were performed by considering the infrared spectral data of 2-aminomethylpyridine that have very similar chemical groups to those of 3-aminomethylpyridine. It has been noted that infrared data on the ampy complexes are not abundant in the literature. Only a few papers have been found in the literature concerning the geometric parameters of 2-aminomethylpyridine ligands and calculation of vibration frequencies [20,21]. Depending on the ligand and the metal coordination environment, 3-aminomethylpyridine can act as a bridging ligand, monodentate ligand or a chelating ligand. The 3-aminomethylpyridine can coordinate to metal ions by nitrogen atom of the pyridine ring and amino nitrogen atom and show a bridged ligand feature. In the literature, there are a limited number of structurally characterized complexes of metal(II) tetracyanometallate with 3-aminomethylpyridine as a ligand, which encouraged us to study the complexation tendency of $\mathrm{Cd}$ (II) with 3-aminomethylpyridine in the presence of the ambidentate cyano ligand [18, 23, 24].

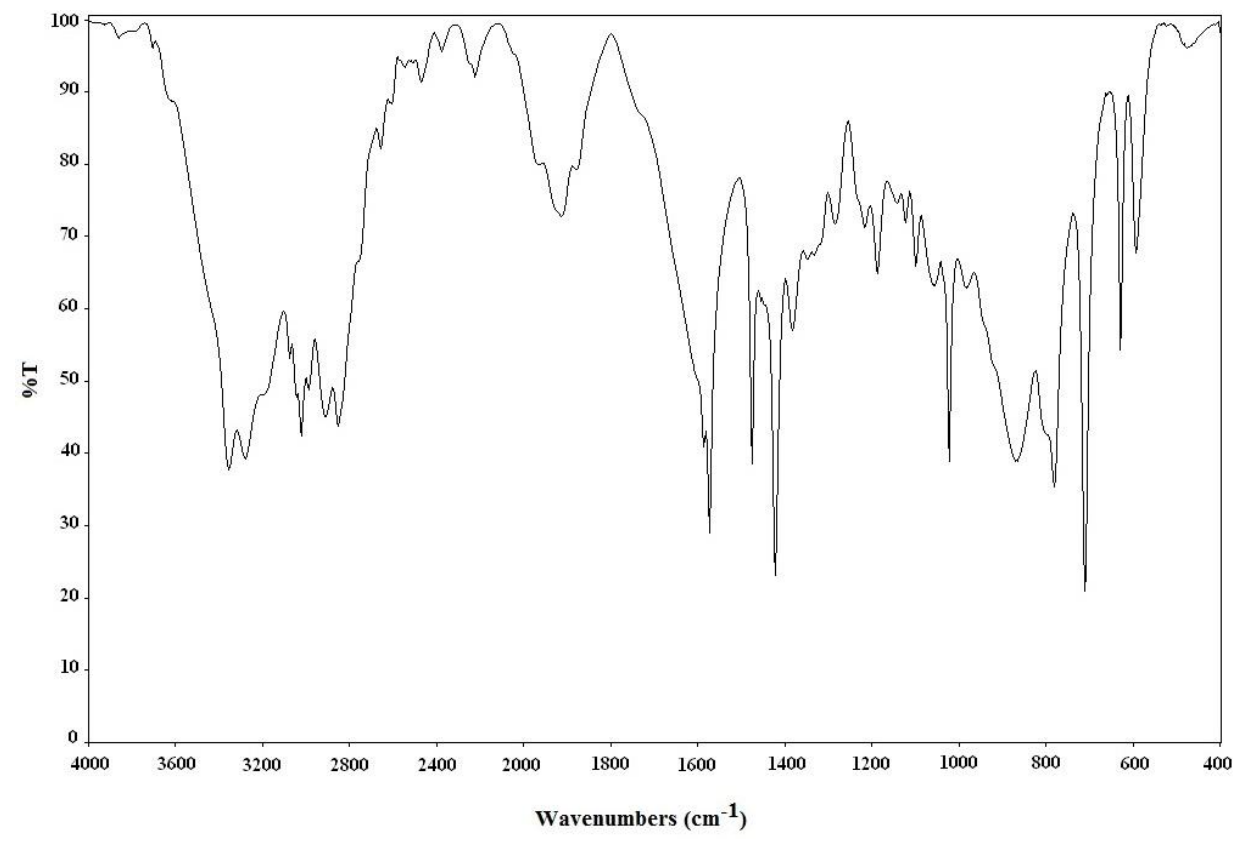

Figure 2. The infrared spectra of the ampy ligand 
Karaağaç / Eskişehir Technical Univ. J. of Sci. and Tech. A-Appl. Sci. and Eng. 20 (3) - 2019

Table 2. The vibrational wavenumbers $\left(\mathrm{cm}^{-1}\right)$ of the ampy in the complexes

\begin{tabular}{|c|c|c|c|c|c|c|c|c|}
\hline \multirow[t]{2}{*}{ Assignment [20] } & \multirow{2}{*}{$\begin{array}{l}\text { ampy } \\
\text { Exp. }\end{array}$} & \multirow[t]{2}{*}{ Cu-amp-SCN [20] } & \multicolumn{2}{|c|}{ Cd-Ni-ampy [18] } & \multicolumn{2}{|c|}{ Co-Ni-ampy } & \multicolumn{2}{|c|}{ Ni-Ni-ampy } \\
\hline & & & FT-IR & Raman & FT-IR & Raman & FT-IR & Raman \\
\hline$v\left(\mathrm{NH}_{2}\right)$ asym str of $\mathrm{N}-\mathrm{H}$ in $\mathrm{NH}_{2}$ & $3363 \mathrm{~s}$ & 3567 & $3373 \mathrm{~m}$ & - & $3373 \mathrm{~m}$ & - & $3353 \mathrm{~m}$ & $3352 \mathrm{vw}$ \\
\hline$v\left(\mathrm{NH}_{2}\right)$ sym str of $\mathrm{N}-\mathrm{H}$ in $\mathrm{NH}_{2}$ & $3289 \mathrm{~s}$ & 3502 & $3298 \mathrm{~m}$ & - & $3342 \mathrm{w}$ & - & $3289 w$ & $3299 \mathrm{w}$ \\
\hline$v\left(\mathrm{NH}_{2}\right)^{\mathrm{a}}$ & $3199 \mathrm{sh}$ & - & $3178 \mathrm{w}$ & - & $3141 \mathrm{w}$ & - & $3157 \mathrm{w}$ & $3177 \mathrm{vw}$ \\
\hline$v(\mathrm{CH})^{\mathrm{a}}$ & $3052 \mathrm{~s}$ & - & - & $3067 \mathrm{vw}$ & $3069 \mathrm{vw}$ & $3066 \mathrm{vw}$ & $3085 \mathrm{vw}$ & $3065 \mathrm{~m}$ \\
\hline$v(\mathrm{CH})$ sym str of $\mathrm{C}-\mathrm{H}$ in py ring & $2996 \mathrm{~s}$ & 3190 & $3023 \mathrm{vw}$ & - & $2998 \mathrm{vw}$ & - & $3043 \mathrm{vw}$ & - \\
\hline$v\left(\mathrm{CH}_{2}\right)^{\mathrm{a}}$ & $2918 \mathrm{~s}$ & - & $2923 \mathrm{w}$ & $2931 \mathrm{vw}$ & $2926 \mathrm{vw}$ & - & $2948 \mathrm{w}$ & 2964 w \\
\hline$v\left(\mathrm{CH}_{2}\right)$ sym str of $\mathrm{C}-\mathrm{H}$ in $\mathrm{CH}_{2}$ & $2861 \mathrm{~s}$ & 3025 & $2847 \mathrm{vw}$ & - & $2885 \mathrm{vw}$ & - & $2869 \mathrm{vw}$ & - \\
\hline$v \mathrm{C}=\mathrm{N}) \mathrm{C}=\mathrm{N}$ str & $1617 \mathrm{sh}$ & 1659 & - & - & - & - & - & - \\
\hline$\delta\left(\mathrm{NH}_{2}\right) \mathrm{NH}_{2}$ scissoring & $1590 \mathrm{~s}$ & 1632 & $1594 \mathrm{~m}$ & $1602 \mathrm{w}$ & $1605 \mathrm{~s}$ & $1618 \mathrm{w}$ & $1590 \mathrm{~s}$ & $1614 \mathrm{w}$ \\
\hline$v(\mathrm{CC})$ asym str of $\mathrm{C}=\mathrm{C}$ in py ring & $1576 \mathrm{~s}$ & 1602 & $1580 \mathrm{w}$ & $1590 \mathrm{sh}$ & $1586 \mathrm{sh}$ & $1592 \mathrm{sh}$ & $1577 \mathrm{sh}$ & $1598 \mathrm{sh}$ \\
\hline$\delta\left(\mathrm{CH}_{2}\right)^{\mathrm{a}}$ & $1479 \mathrm{~s}$ & - & $1480 \mathrm{~m}$ & $1488 \mathrm{vw}$ & $1467 \mathrm{vw}$ & $1482 \mathrm{vw}$ & $1482 \mathrm{~m}$ & - \\
\hline$\delta\left(\mathrm{CH}_{2}\right)$ rocking in py, scissoring in $\mathrm{CH}_{2}$ & 1426 vs & 1464 & $1438 \mathrm{~m}$ & $1446 \mathrm{vw}$ & $1434 \mathrm{~s}$ & $1446 \mathrm{w}$ & $1441 \mathrm{sh}$ & $1448 \mathrm{w}$ \\
\hline $\mathrm{w}\left(\mathrm{CH}_{2}\right)$ wagging in $\mathrm{CH}_{2}$ group & $1388 \mathrm{~m}$ & 1389 & $1426 \mathrm{~m}$ & $1416 \mathrm{vw}$ & $1397 \mathrm{w}$ & - & $1432 \mathrm{~m}$ & $1419 \mathrm{vw}$ \\
\hline $\mathrm{t}\left(\mathrm{CH}_{2}\right)^{\mathrm{a}}$ & $1385 \mathrm{~m}$ & - & $1354 \mathrm{w}$ & $1361 \mathrm{vw}$ & $1384 \mathrm{vw}$ & $1380 \mathrm{sh}$ & $1368 \mathrm{w}$ & $1372 \mathrm{vw}$ \\
\hline Ip bending of $\mathrm{C}-\mathrm{H}$, asym bend in py & $1336 \mathrm{vw}$ & 1309 & - & - & $1356 \mathrm{vw}$ & - & $1334 \mathrm{w}$ & - \\
\hline $\mathrm{t}\left(\mathrm{NH}_{2}\right)^{\mathrm{a}}$ & $1288 \mathrm{w}$ & - & $1316 \mathrm{w}$ & $1329 \mathrm{vw}$ & - & - & - & $1311 \mathrm{vw}$ \\
\hline scissoring in py ring & $1191 \mathrm{~m}$ & 1183 & $1222 \mathrm{~m}$ & - & $1229 \mathrm{~m}$ & $1243 \mathrm{w}$ & $1224 \mathrm{vw}$ & $1245 \mathrm{w}$ \\
\hline$v(\text { skeletal })^{\mathrm{a}}$ & $1146 \mathrm{~m}$ & - & $1130 \mathrm{w}$ & $1189 \mathrm{vw}$ & $1195 \mathrm{~m}$ & $1205 \mathrm{w}$ & $1194 \mathrm{~m}$ & $1200 \mathrm{w}$ \\
\hline$v(\text { skeletal })^{\mathrm{a}}$ & $1102 \mathrm{~m}$ & - & $1071 w$ & $1140 \mathrm{vw}$ & $1141 \mathrm{vw}$ & $1143 \mathrm{vw}$ & $1129 \mathrm{w}$ & - \\
\hline$v$ (skeletal) Ip bending in py ring & $1060 \mathrm{~m}$ & 1082 & $1050 \mathrm{~m}$ & $1080 \mathrm{w}$ & $1103 \mathrm{w}$ & $1088 \mathrm{sh}$ & $1110 \mathrm{w}$ & $1086 \mathrm{sh}$ \\
\hline$v($ skeletal $) v(\mathrm{C}-\mathrm{N})^{\mathrm{a}}$ & $1027 \mathrm{~s}$ & - & $1030 \mathrm{~m}$ & $1043 \mathrm{~m}$ & $1055 \mathrm{~m}$ & $1056 \mathrm{vs}$ & $1048 \mathrm{~m}$ & $1048 \mathrm{~s}$ \\
\hline$v($ skeletal) scissoring in py ring & $988 \mathrm{~s}$ & 1036 & $937 \mathrm{~m}$ & $993 \mathrm{vw}$ & $1034 \mathrm{~m}$ & - & $1007 \mathrm{~s}$ & - \\
\hline $\mathrm{t}\left(\mathrm{CH}_{2}\right)^{\mathrm{a}}$ & $873 \mathrm{~s}$ & - & $901 \mathrm{w}$ & $914 \mathrm{vw}$ & $940 \mathrm{~m}$ & $920 \mathrm{vw}$ & $876 \mathrm{~m}$ & $887 \mathrm{vw}$ \\
\hline $\mathrm{r}\left(\mathrm{CH}_{2}\right), \mathrm{w}\left(\mathrm{NH}_{2}\right)^{\mathrm{a}}$ & $802 \mathrm{sh}$ & - & $805 \mathrm{vw}$ & 804 vw & $880 \mathrm{vw}$ & - & - & - \\
\hline rocking of $\mathrm{C}-\mathrm{H}$ in py ring & $785 \mathrm{~m}$ & 768 & $785 \mathrm{~m}$ & - & $796 \mathrm{~s}$ & $814 \mathrm{~m}$ & $790 \mathrm{~s}$ & $820 w$ \\
\hline rocking in $\mathrm{NH}_{2}$ & 714 vs & 706 & $705 \mathrm{~s}$ & - & $706 \mathrm{vs}$ & - & $710 \mathrm{~s}$ & $728 \mathrm{vw}$ \\
\hline sym str in py ring & $632 \mathrm{~m}$ & 660 & $645 w$ & $657 \mathrm{vw}$ & $649 \mathrm{~m}$ & $664 \mathrm{w}$ & $649 w$ & $661 \mathrm{w}$ \\
\hline wagging in $\mathrm{NH}_{2}$ & $596 \mathrm{~m}$ & 614 & $604 \mathrm{w}$ & $618 \mathrm{vw}$ & $613 \mathrm{vw}$ & $622 w$ & $634 \mathrm{vw}$ & $621 \mathrm{vw}$ \\
\hline
\end{tabular}

Abbreviations used: $v$ stretching, $\delta$ deformation, w wagging, t twisting, r rocking, py pyridine,str stretching, asym asymmetric, sym symmetric, ip in plane, s strong, m medium, w weak, sh shoulder, v very.

${ }^{a}$ Assignments are taken from ref. [22]

The ampy ligand has two nitrogen atoms, each of which is an unpaired electron pair. For this reason, the ampy ligand can be found in the complex formation through the ring nitrogen and amino nitrogen atoms. The ampy ligand is represented by a large number of absorption bands including $v\left(\mathrm{NH}_{2}\right), v(\mathrm{CH})$, $\delta\left(\mathrm{NH}_{2}\right), v(\mathrm{CC}), \delta\left(\mathrm{CH}_{2}\right), v\left(\right.$ skeletal), rocking of $\mathrm{C}-\mathrm{H}$ in py ring, rocking in $\mathrm{NH}_{2}$ and other vibrational bands. Table 1 shows that the ampy ligand has infrared bands arising from the $v\left(\mathrm{NH}_{2}\right)$ asymmetric and symmetric stretching frequencies in the $3363-3289 \mathrm{~cm}^{-1}$ range. These vibration bands, complex CoNi-ampy are assigned at $3373 \mathrm{~cm}^{-1}$ and $3342 \mathrm{~cm}^{-1}$ (at $3373 \mathrm{~cm}^{-1}$ and $3298 \mathrm{~cm}^{-1}$ for Cd-Ni-ampy), while complex Ni-Ni-ampy are assigned at $3353 \mathrm{~cm}^{-1}$ and $3289 \mathrm{~cm}^{-1}$ (at $3352 \mathrm{~cm}^{-1}$ and $3299 \mathrm{~cm}^{-1}$ for Raman), respectively. The $v\left(\mathrm{NH}_{2}\right)$ asymmetric and symmetric stretching frequencies of the ampy ligand in CoNi-ampy were significantly shifted to higher frequency according to the free ligand in a similar manner to the complex Cd-Ni-ampy. On the other hand, the band about $1590 \mathrm{~cm}^{-1}$ assigned to the $\delta\left(\mathrm{NH}_{2}\right)$ bending vibrations and this band in the infrared and Raman spectra of the complexes shifted to higher frequency in the range of 0-28 $\mathrm{cm}^{-1}$ comparing to the free ligand. In addition, no change was observed with respect to the free ligand in the $\delta\left(\mathrm{NH}_{2}\right)$ bending vibrations of the ampy ligand in infrared spectra of complex Ni-Ni-ampy. In this case, we can say that the ampy ligand in complex Ni-Ni-ampy is not coordinated to the metal atom through the amine nitrogen, while the ampy coordinates to the metal atom through the amine nitrogen atom in complex Co-Ni-ampy.

When the nitrogen of the pyridine ring was found in complex formation, certain vibrational modes increase in value owing to the coupling the internal vibration modes of the ampy with M-N(pyridine) bond vibrations $[14,25]$. The most important vibrational bands for the coordination to the metal atom via the nitrogen of the pyridine ring in the ampy ligand are $\mathrm{v}(\mathrm{CH})$ in pyridine ring, rocking of $\mathrm{C}-\mathrm{H}$ in pyridine ring, symmetric stretching in pyridine ring, scissoring in pyridine ring and $v$ (skeletal) vibrations. Especially, these bands in the infrared and Raman spectra of the complexes are showed a 
significant upward shift according to the free ligand. The ring $v(\mathrm{CH})$ modes of the ampy were found at $3052 \mathrm{~cm}^{-1}$, and $2996 \mathrm{~cm}^{-1}$ and the $v(\mathrm{CH})$ stretching bands in the infrared spectra of the complexes have been assigned at $3069 \mathrm{~cm}^{-1}$ (at $3066 \mathrm{~cm}^{-1}$ for Raman) and $2998 \mathrm{~cm}^{-1}$ (for Co-Ni-ampy) and at $3085 \mathrm{~cm}^{-}$ ${ }^{1}$ (at $3065 \mathrm{~cm}^{-1}$ for Raman) and $3043 \mathrm{~cm}^{-1}$ (for Ni-Ni-ampy). The pyridine ring bands in the infrared spectra of the ampy appear in $1200-980 \mathrm{~cm}^{-1}$ region and at $632 \mathrm{~cm}^{-1}$. These bands of pyridine are shifted by $17-59 \mathrm{~cm}^{-1}$ to a higher frequency on complexation. Therefore, these results suggest that the ring nitrogen of the ampy for the both complexes is involved in complex formation.

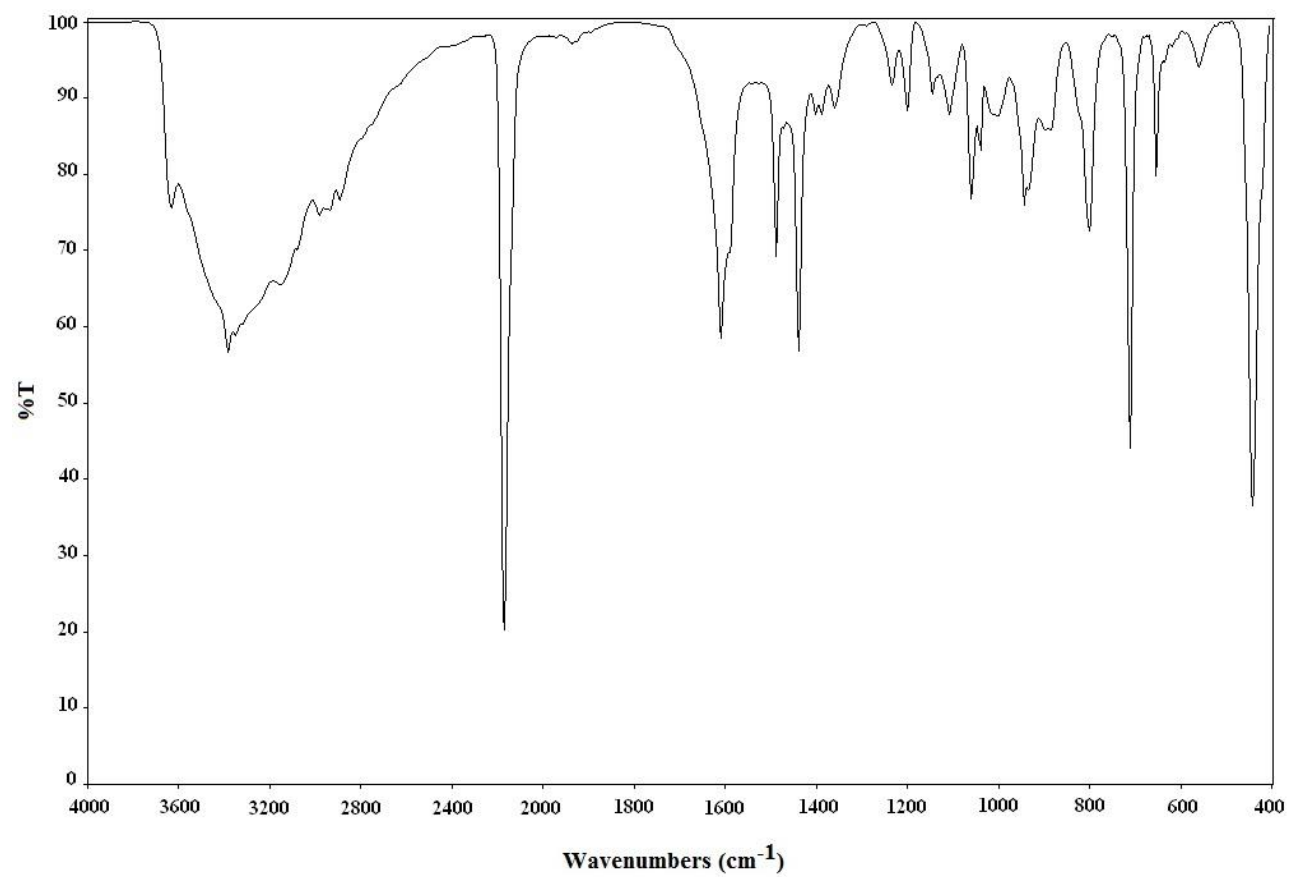

(a)

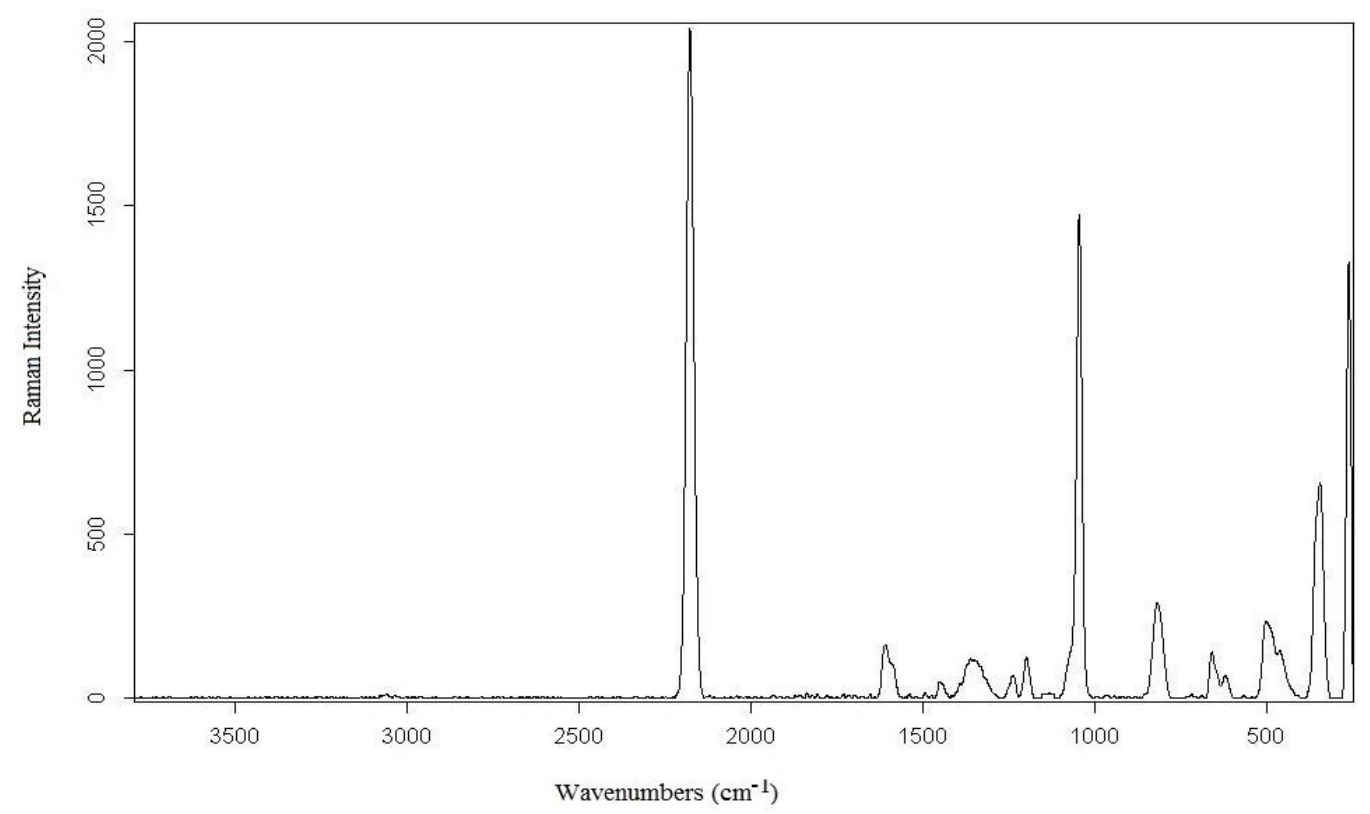

(b)

Figure 3. The infrared (a) and Raman (b) spectrum of Co-Ni-ampy 
Karaağaç / Eskişehir Technical Univ. J. of Sci. and Tech. A-Appl. Sci. and Eng. 20 (3) - 2019

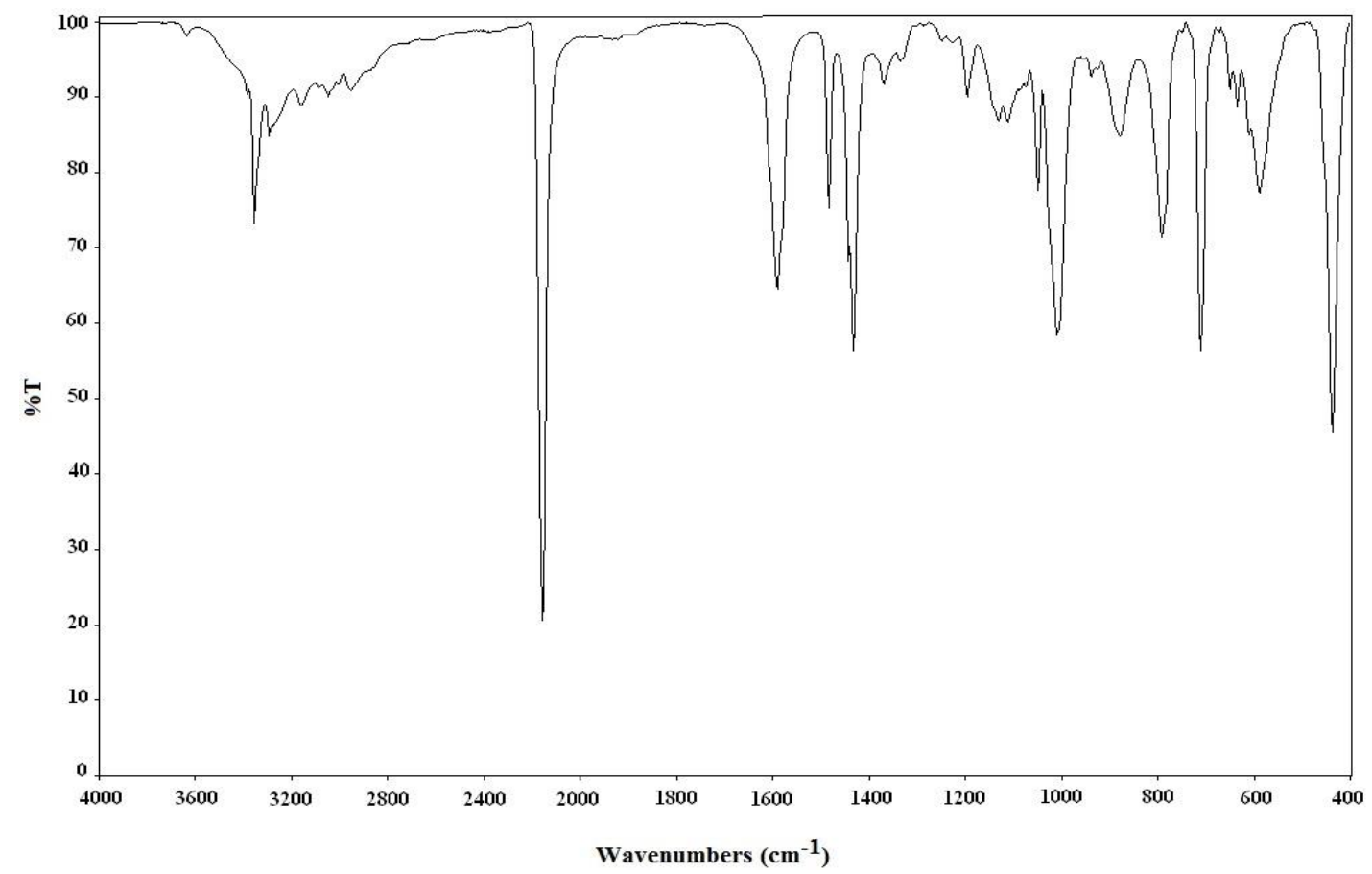

(a)

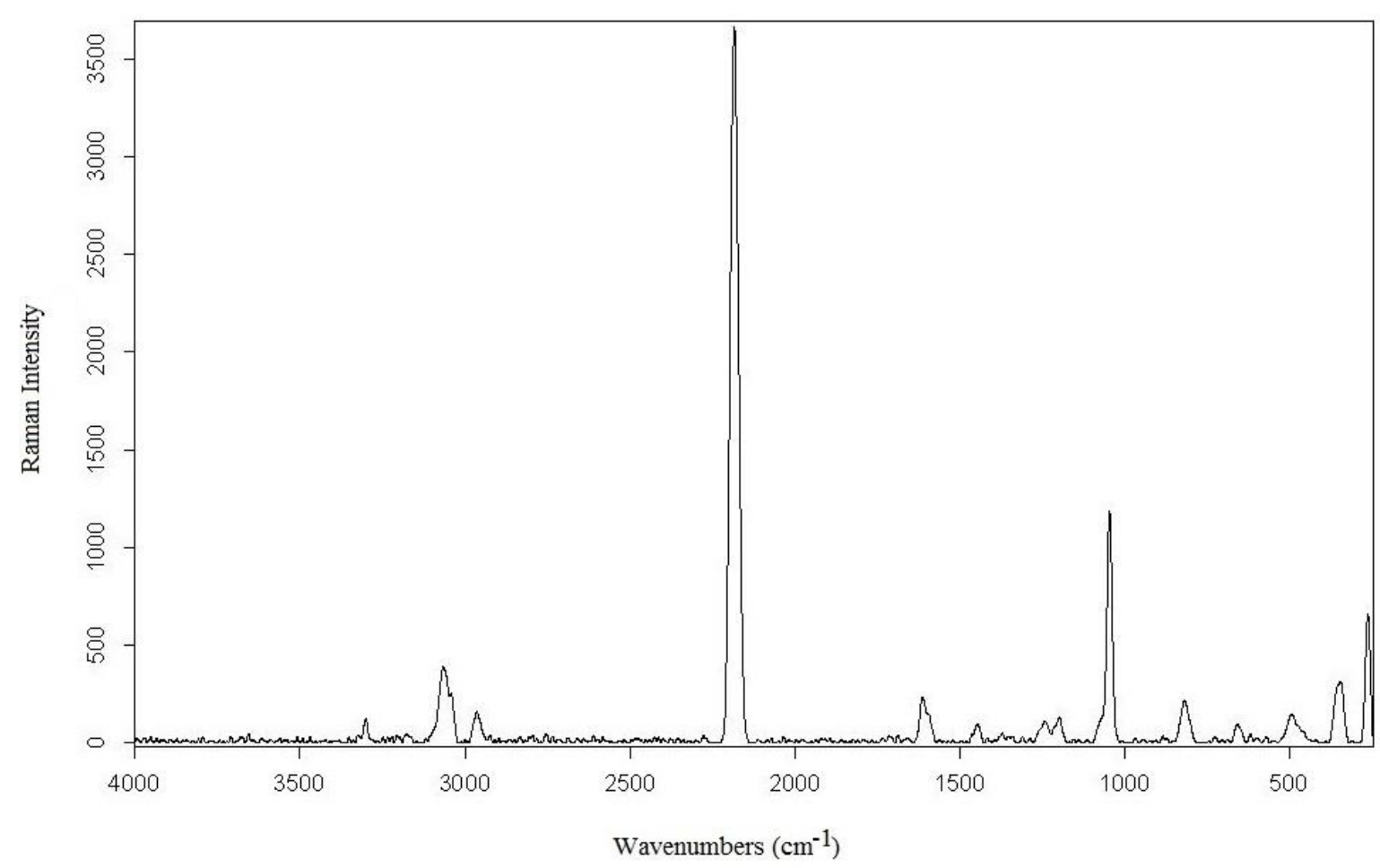

(b)

Figure 4. The infrared (a) and Raman (b) spectrum of Ni-Ni-ampy

\subsubsection{Water vibrations}

There are three vibration bands that originate from $v(\mathrm{OH})$ (the asymmetric and symmetric stretching) and $\delta(\mathrm{HOH})$ (bending) vibrations of water molecules. Coordinated and uncoordinated water molecules are found in Co-Ni-ampy, while one stretching band corresponding to uncoordinated water molecules 
is observed in the infrared spectrum of Ni-Ni-ampy. The water molecules found in infrared spectra of the complexes show infrared absorptions at $3623 \mathrm{~cm}^{-1}\left[\mathrm{v}(\mathrm{OH})\right.$ for Co-Ni-ampy)] and $3630 \mathrm{~cm}^{-1}[\mathrm{v}(\mathrm{OH})$ for Ni-Ni-ampy)]. In addition, $\delta(\mathrm{HOH})$ bending bands with the $\delta(\mathrm{HOH})$ bending bands of the water molecules in Co-Ni-ampy and Ni-Ni-ampy overlap around $1605 \mathrm{~cm}^{-1}$ and $1588 \mathrm{~cm}^{-1}$, respectively.

\subsection{3. $\left[\mathrm{Ni}(\mathrm{CN})_{4}\right]^{2-}$ Group vibrations}

The vibration assignments and wavenumbers of the $\left[\mathrm{Ni}(\mathrm{CN})_{4}\right]^{2-}$ group in the complexes are given in Table 3, together with the vibration wavenumbers of $\mathrm{K}_{2}\left[\mathrm{Ni}(\mathrm{CN})_{4}\right] \cdot \mathrm{H}_{2} \mathrm{O}$ in the solid phase. The assignments of vibration bands of the $\left[\mathrm{Ni}(\mathrm{CN})_{4}\right]^{2-}$ group in the complexes are assigned on the basis of the ion $\left[\mathrm{Ni}(\mathrm{CN})_{4}\right]^{2-}$ in $\mathrm{Na}_{2}\left[\mathrm{Ni}(\mathrm{CN})_{4}\right]$ reported by McCullough et al [26]. The most important vibration bands of the $\left[\mathrm{Ni}(\mathrm{CN})_{4}\right]^{2-}$ group are strong and sharp the $v(\mathrm{CN})$ stretching vibration band and the $\delta(\mathrm{Ni}-$ $\mathrm{CN}$ ) in-plane bending vibration band [27, 28]. These stretching and in-plane bending vibrations exhibit strong and sharp absorption bands in the range of $(2200-2100) \mathrm{cm}^{-1}$ and $(450-400) \mathrm{cm}^{-1}$ for cyanometallate complexes, respectively. In the synthesized tetracyanonickellate anion, the $v(\mathrm{CN})$ stretching vibration band is shown at $2122 \mathrm{~cm}^{-1}$. The coordination to second metal of the cyano group through the $\mathrm{N}$ atom in the tetracyanonickellate anion shifts the position of the $v(\mathrm{CN})$ absorption band to higher wavenumbers due to the kinematic coupling [29-31]. The $v(\mathrm{CN})$ stretching vibration frequencies in the infrared spectra of both Co-Ni-ampy and Ni-Ni-ampy are observed as a single peak at $2162 \mathrm{~cm}^{-1}\left(2135 \mathrm{~cm}^{-1}\right.$ for Cd-Ni-ampy) and $2152 \mathrm{~cm}^{-1}$, respectively. From the infrared spectra of the complexes, it is determined that the stretching vibration of cyano has shifted to $30 \mathrm{~cm}^{-1}$ and $40 \mathrm{~cm}^{-1}$ higher frequency, respectively. The appearance of a single cyano stretching peak in the synthesized complexes indicates that the four cyano groups act as bridge ligands. In the resulting complexes, the $\mathrm{A}_{1 \mathrm{~g}}$ cyano stretching mode is observed at $2182 \mathrm{~cm}^{-1}$ (for Co-Ni-ampy) and $2184 \mathrm{~cm}^{-1}$ (for $\mathrm{Ni}-\mathrm{Ni}$-ampy) but $\mathrm{B}_{1 \mathrm{~g}}$ cyano stretching mode is not observed. In the Raman spectra of the complexes, the $\mathrm{A}_{1 \mathrm{~g}}$ mode shifted to higher wavenumbers around $23 \mathrm{~cm}^{-1}$ compared to those of the free $\left[\mathrm{Ni}(\mathrm{CN})_{4}\right]^{2-}$ groups. On the other hand, the $\delta(\mathrm{Ni}-\mathrm{CN})$ in-plane bending vibration band of $\mathrm{K}_{2}\left[\mathrm{Ni}(\mathrm{CN})_{4}\right] \cdot \mathrm{H}_{2} \mathrm{O}$ is found as one strong and sharp band at $414 \mathrm{~cm}^{-1}$. In infrared spectra of Co-Ni-ampy and Ni-Ni-ampy, the $\delta(\mathrm{Ni}-\mathrm{CN})$ bands appear as strong bands at $438 \mathrm{~cm}^{-1}$ and $436 \mathrm{~cm}^{-1}$, respectively. In-plane bending vibration band, $\delta(\mathrm{Ni}-$ $\mathrm{CN})$ shifts to a higher frequency and support the $v(\mathrm{CN})$ stretching vibration band. The $v(\mathrm{CN})$ and $\delta(\mathrm{Ni}-$ $\mathrm{CN}$ ) vibrational wavenumbers of the $\left[\mathrm{Ni}(\mathrm{CN})_{4}\right]^{2-}$ group in the complexes are found to be similar to those of cyano-bridged complexes [32,33].

Table 3. The vibrational wavenumbers of the $\left[\mathrm{Ni}(\mathrm{CN})_{4}\right]^{2-}$ group in the complexes $\left(\mathrm{cm}^{-1}\right)$

\begin{tabular}{lcccc}
\hline Assignment [26] & $\mathrm{K}_{2}\left[\mathrm{Ni}(\mathrm{CN})_{4}\right] \cdot \mathrm{H}_{2} \mathrm{O}$ & $\mathrm{Cd}-\mathrm{Ni}$-ampy [18] & Co-Ni-ampy & Ni-Ni-ampy \\
\hline $\mathrm{A}_{1 \mathrm{~g}}, v(\mathrm{CN})$ & $(2160) \mathrm{vs}$ & $(2168) \mathrm{vs}$ & $(2182) \mathrm{vs}$ & $(2184) \mathrm{vs}$ \\
$\mathrm{B}_{1 \mathrm{~g}}, v(\mathrm{CN})$ & $(2137) \mathrm{m}$ & - & - & - \\
$\mathrm{E}_{\mathrm{u}}, v(\mathrm{CN})$ & $2122 \mathrm{vs}$ & $2159 \mathrm{sh}, 2146 \mathrm{sh}, 2135 \mathrm{vs}$ & $2162 \mathrm{vs}$ & $2152 \mathrm{vs}$ \\
$\mathrm{E}_{\mathrm{u}}, v\left({ }^{13} \mathrm{CN}\right)$ & $2084 \mathrm{w}$ & $2102 \mathrm{sh}$ & - & - \\
$\mathrm{E}_{\mathrm{u}}, v(\mathrm{NiC})$ & $542 \mathrm{w}$ & $531 \mathrm{~m}$ & $556 \mathrm{w}$ & $586 \mathrm{w}$ \\
$\mathrm{A}_{2 \mathrm{u}}, \pi(\mathrm{NiCN})$ & $443 \mathrm{w}$ & $463 \mathrm{w}$ & - & - \\
$\mathrm{E}_{\mathrm{u}}, \delta(\mathrm{NiCN})$ & $414 \mathrm{~s}$ & $420 \mathrm{~s}$ & $438 \mathrm{vs}$ & $436 \mathrm{vs}$ \\
\hline
\end{tabular}

Abbreviations used; s strong, m medium, w weak, sh shoulder, $v$ very. The symbols $v, \delta$, and $\pi$ refer to valence, in-plane and out-of-plane vibrations, respectively. The vibrational frequencies in the Raman spectrum are enclosed in parentheses.

According to the obtained spectroscopic results, it was found that the ampy ligand in complex Co-Niampy coordinate to the metal atoms (Co and $\mathrm{Ni}$ ) via the pyridine ring nitrogen and amino nitrogen atoms, whereas the ampy ligand in complex Ni-Ni-ampy coordinates to the metal $(\mathrm{Ni})$ via the pyridine ring nitrogen atom. The cyano ligand also acts as a bridge ligand in the complexes. In this case, it is considered that the structures of the complexes according to the obtained spectral data are as shown in Figures 1 and 5. As seen in Figure 1, the $\mathrm{NH}_{3}$ in the crystal structure of complex Cd-Ni-ampy is replaced by $\mathrm{H}_{2} \mathrm{O}$ ligand in complex Co-Ni-ampy. 


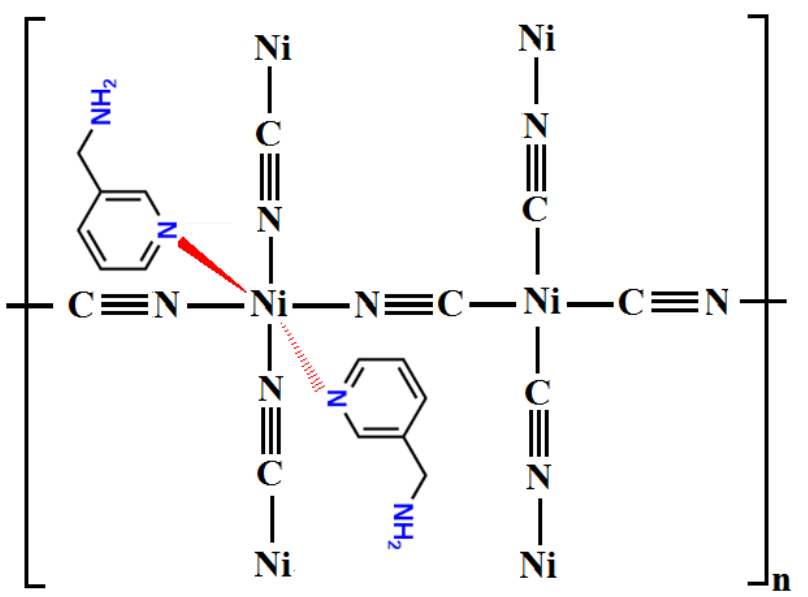

Figure 5. The representative molecular structures of complex Ni-Ni-ampy

\subsection{Thermal Analyses}

Thermal decomposition behaviors of the complexes were performed by TG, DTG and DTA methods in the temperature range of $30-700{ }^{\circ} \mathrm{C}$ in static atmosphere of air. The thermal decomposition curves for Co-Ni-ampy and Ni-Ni-ampy are shown in Figures 6 and 7. Thermal decomposition of Co-Ni-ampy takes place in the two stages. In the first stage, complex Co-Ni-ampy loses both coordinated and uncoordinated water molecules in a single step in the temperature range of $30-162{ }^{\circ} \mathrm{C}$ [Found (Calcd.) $(\%)=7.22(9.85)]$. In following stage, one ampy ligand and four cyanide ligands are separated from the structure in the temperature range of $162-374^{\circ} \mathrm{C}$ [Found (Calcd.) $(\%)=55.65(58.00)$ ] and exothermic peak appears at ca. $329^{\circ} \mathrm{C}$ in the DTA curve. The final decomposition products were identified as $\mathrm{CoO}$ and $\mathrm{NiO}$ [Found (Calcd.) $(\%)=37.13(40.68)$ ]. Complex Ni-Ni-ampy is stable up to $40^{\circ} \mathrm{C}$ and after that the complex is degraded in two stages. In the first stage, one uncoordinated water and one ampy ligand between $40{ }^{\circ} \mathrm{C}$ and $363{ }^{\circ} \mathrm{C}$ are released [Found (Calcd.) $(\%)=24.13(27.68)$ ]. In the second stage, within $363-694{ }^{\circ} \mathrm{C}$ the decomposition continues with liberating of one ampy ligand and four cyanide ligands [Found (Calcd.) $(\%)=43.01(46.56)]$ exothermic peak appears at ca. $378{ }^{\circ} \mathrm{C}$ in the DTA curve. The final residue product was found to be $2(\mathrm{NiO})$ [Found (Calcd.) $(\%)=32.86(32.77)$ ] and they are identified by FT-IR spectroscopy. The recorded TG, DTG and DTA curves promoted the formula unit found from elemental analyses and the vibrational spectroscopic studies of the complexes.

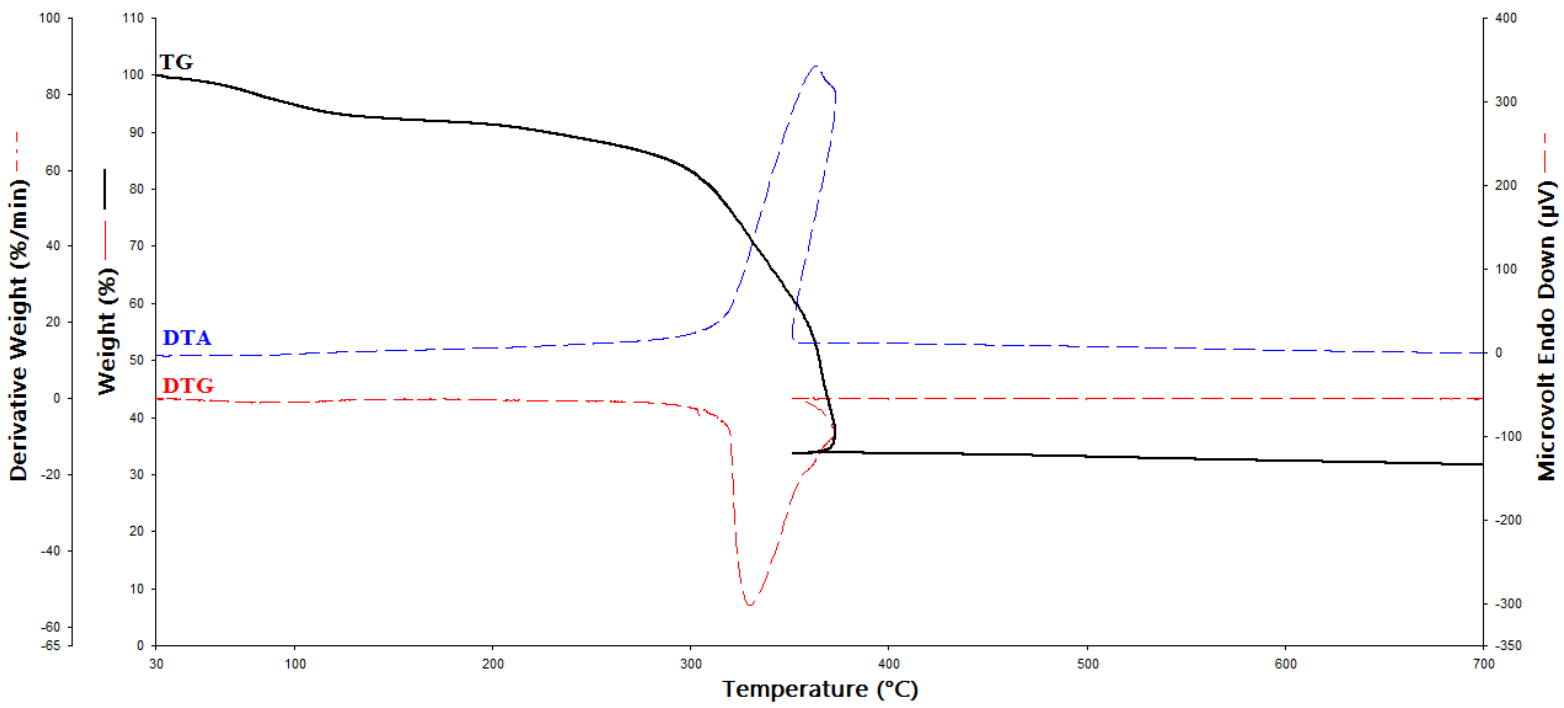

Figure 6. The TG, DTG and DTA curves of Co-Ni-ampy 


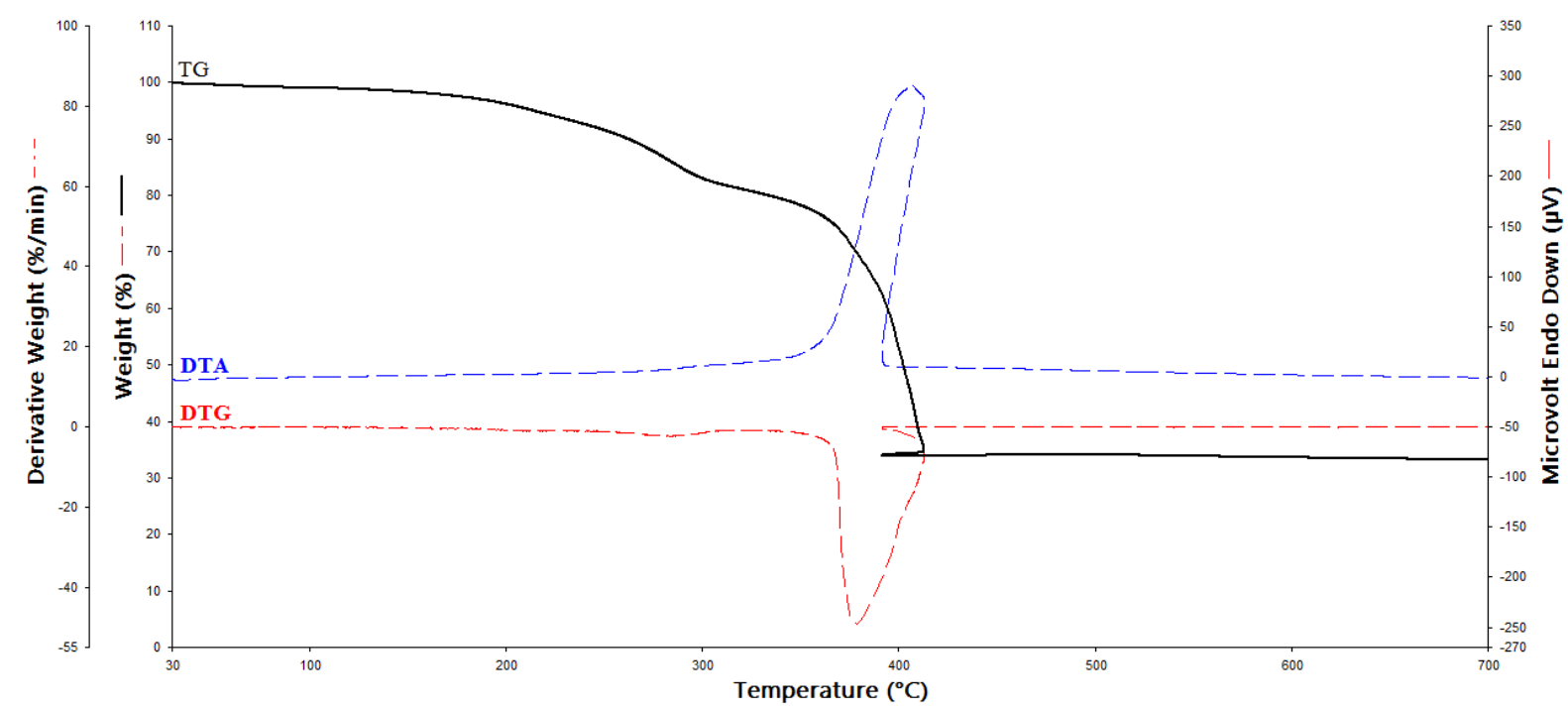

Figure 7. The TG, DTG and DTA curves of Ni-Ni-ampy

\section{CONCLUSION}

Here we report the results of our study on synthesis and thermal, elemental and spectral characterization of $\left[\mathrm{Co}\left(\mathrm{H}_{2} \mathrm{O}\right)(\right.$ ampy $\left.) \mathrm{Ni}(\mathrm{CN})_{4}\right] \cdot \mathrm{H}_{2} \mathrm{O}$ and $\left[\mathrm{Ni}(\text { ampy })_{2} \mathrm{Ni}(\mathrm{CN})_{4}\right] \cdot \mathrm{H}_{2} \mathrm{O}$ (ampy = 3-aminomethylpyridine). In previous study, structure of complex $\left[\mathrm{Cd}\left(\mathrm{NH}_{3}\right)(\operatorname{ampy}) \mathrm{Ni}(\mathrm{CN})_{4}\right]_{\mathrm{n}}$ was determined by single crystal $\mathrm{X}$ ray diffraction methods. The $\mathrm{Ni}$ (II) ions are five coordinate with four cyanide-carbon atoms and one ampy ligand in pyramidal and the Cd(II) ion exhibits a distorted octahedral coordination by one ampy and one ammonia ligand and four bridging cyano groups. Vibration assignments are given for all the observed bands and the spectral feature also supported to the structure of cyano-bridged polymeric complexes. Spectroscopic results show that Cd-Ni-ampy with Co-Ni-ampy are similar to each other and the ampy ligand is coordinated to metal ions as bidentate ligand. The spectral data obtained indicate that complex Ni-Ni-ampy is similar in structure to the Hofmann type complexes and its structure consists of polymeric layers of $\left|\mathrm{Ni}-\mathrm{Ni}(\mathrm{CN})_{4}\right|_{\infty}$ with the ampy ligand bounded to the nickel(II) atom. The ampy ligands in complex Ni-Ni-ampy have been coordinated as a monodentate ligand bonding only through pyridine ring nitrogen of the ampy ligand. These polymeric layers are held in parallel by Van der Walls interactions between the ampy ligands. Thermal analyses of the complexes are also supported the spectroscopic conclusion.

\section{ACKNOWLEDGEMENT}

I would like to thank Prof. Dr. Güneş Süheyla Kürkçüoğlu for his support in writing of this article. This work was supported by the Research Fund of Eskişehir Osmangazi University. Project number: 201219024.

\section{REFERENCES}

[1] Legendre A, Correa JRA, Bannach G, Mauro A, Ionashiro M. An investigation of the thermal behavior of heterobimetallic species containing copper(II) and tetracyanopalladate(II). J Therm Anal. 2007; 87: 779-782.

[2] Lefebvre J, Batchelor RJ, Leznoff DB. Cu $\left[\mathrm{Au}(\mathrm{CN})_{2}\right]_{2}(\mathrm{DMSO})_{2}$ : golden polymorphs that exhibit vapochromic behavior. J Am Chem Soc. 2004; 126: 16117-1625. 
[3] Karadag A, Önal İ, Senocak A, Uçar İ, Bulut A, Büyükgüngör O. Syntheses, IR spectra, thermal properties and crystal structures of novel cyano-bridged polymeric complexes of zinc(II) and cadmium(II) with tetracyanoplatinate(II). Polyhedron. 2008; 27: 223-231.

[4] Iwamoto T. Inclusion Compounds. JL Atwood, JED Davies, and DD Mc Nicol (eds). 1991; 5: 177.

[5] Iwamoto T. Comprehensive Supramolecular Chemistry. Vol. 1996; 6: 643.

[6] Cernak J, Orendac M, Potocnak I, Chomic J, Orendacova A, Skorsepa J, Feher A. Cyanocomplexes with one-dimensional structures: preparations, crystal structures and magnetic properties. Coord Chem Rev. 2002; 224: 51-66.

[7] Ohba M, Okawa H. Synthesis and magnetism of multi-dimensional cyanide-bridged bimetallic assemblies. Coord Chem Rev. 2000; 198: 313-328.

[8] Verdaguer M, Bleuzen A, Marvaud V, Vaissermann J, Seuleiman M, Desplanches C, Scuillera A, Traina C, Gardea R, Gellya G, Lomenecha C, Rosenmanb I, Veilletc P, Cartiera C, Villaina F. Molecules to build solids: high TC molecule-based magnets by design and recent revival of cyano complexes chemistry. Coord Chem Rev. 1999; 190: 1023-1047.

[9] Dunbar K, Heintz R. Progress in inorganic chemistry. V. 1997; 45: 283.

[10] Lefebvre J, Leznoff D. In metal and metalloid-containing polymers, Vol. 6. Wiley; 2005.

[11] Blom N, Ludi A, Burgi HB, Tichy K. Thallium dicyanoaurate(I), Tl[Au(CN)2] and cesium dicyanoaurate(I), Cs[Au(CN)2]. Acta Crystallogr C. 1984; 40: 1767-1769.

[12] Rosenzweig A, Cromer DT. The crystal structure of $\mathrm{KAu}(\mathrm{CN})_{2}$. Acta Crystallogr. 1959; 12; 709-712.

[13] Hussain MS, Al-Arfaj A, Naseem Akhtar M, Isab AA. [ $\left.\left\{(\mathrm{CEP})_{2} \mathrm{Au}\right\}^{+}\left\{\mathrm{Au}(\mathrm{CN})_{2}\right\}^{-}\right]$: A compound with gold-gold bonds. Polyhedron. 1996; 15: 2781-2785.

[14] Akyüz S, Dempster A, Morehouse R, Suzuki S. An infrared and Raman spectroscopic study of some metal pyridine tetracyanonickelate complexes. J Mol Struct. 1973; 17: 105-125.

[15] Bayari S, Kantarci Z, Akyüz S. An infrared spectroscopic study on Hofmann-type complexes of dimethyl sulfoxide. J Mol Struct. 1995; 351: 19-24.

[16] Morehouse R, Aytaç K, Ülkü D. Unit-cell dimensions of Hofmann pyridine complexes. Z Kristallogr. 1977; 145: 157-160.

[17] Kürkçüoğlu GS, Karaağaç D, Yeşilel OZ, Taş M. Synthesis, Spectroscopic and Structural Properties of Heteropolynuclear Cyano-Bridged Complexes. J Inorg Organomet Polym Mater. 2012; 22: 324-231.

[18] Karaağac D, Kürkçüoğlu GS, Yeşilel OZ, Hökelek T, Dal H. Synthesis and crystal structure of cyano-bridged three dimensional polyheteronuclear complex. Z Kristallogr. 2012; 227: 639-645.

[19] Karaağaç D, Kürkçüoğlu GS. Syntheses, spectroscopic and thermal analyses of cyanide bridged heteronuclear polymeric complexes: $\left[\mathrm{M}(\mathrm{L})_{2} \mathrm{Ni}(\mathrm{CN})_{4}\right]_{\mathrm{n}}(\mathrm{L}=\mathrm{N}$-methylethylenediamine or $\mathrm{N}$ ethylethylenediamine; M = Ni(II), Cu(II), Zn(II) or Cd(II)). J Mol Struct. 2016; 1105: 263-272. 
[20] Shukla M, Srivastava N, Saha S, Rao T, Sunkari S. Synthesis, structure, UV-Vis-IR spectra, magnetism and theoretical studies on $\mathrm{Cu}^{\mathrm{II}}\left[(2 \text {-aminomethyl)pyridine](thiocyanate) })_{2}\right.$ and comparisons with an analogous $\mathrm{Cu}^{\mathrm{II}}$ complex. Polyhedron. 2011; 30: 754-763.

[21] Kürkçüoğlu GS, Yeşilel OZ, Kavlak İ, Büyükgüngör O. Nickel(II) $\cdots \pi$ interaction in $\left[\mathrm{M}(\mathrm{ampy})_{2} \mathrm{Ni}(\mu-\mathrm{CN})_{2}(\mathrm{CN})_{2}\right]_{\mathrm{n}}(\mathrm{M}=\mathrm{Zn}$ (II) and $\mathrm{Cd}$ (II), ampy = 2-aminomethylpyridine): Syntheses, vibrational spectroscopy, thermal analyses and crystal structures of cyano-bridged heteronuclear polymeric complexes. J Mol Struct. 2009; 920: 220-226.

[22] Niven ML, Percy GC. The infrared spectra (3500-140 $\left.\mathrm{cm}^{-1}\right)$ of the 2,2'-bipyridine, 2aminomethylpyridine and ethylenediamine adducts and the sodium tris-compounds of cobalt(II), nickel (II) and zinc (II) acetylacetonates. Transit Metal Chem. 1978; 3: 267-271.

[23] Feazell RP, Carson CE, Klausmeyer KK. Silver(I) 3-aminomethylpyridine complexes, part 2: Effect of ligand ratio, hydrogen bonding, and $\pi$-stacking with an interacting anion. Inorg Chem. 2006; 45: 2635-2643.

[24] Barquín M, González Garmendia MJ, Pacheco S, Pinilla E, Quintela S, Seco JM, Torresb MR. Synthesis, crystal structure, magnetic properties and EPR spectra of copper(II) acetate derivatives: tetra-( $\mu$-acetato)bis(2-methylaminopyridine)copper(II) and catena-poly(aquadiacetato- $\mu$-3aminomethylpyridine)copper(II). Sheets formed by chains connected through hydrogen-bonds. Inorg Chim Acta. 2004; 357: 3230-3236.

[25] Suzuki S, Orvilelle-Thomas W. Molecular force field of pyridine and its application to pyridinemetal complexes. J Mol Struct. 1977; 37: 321-327.

[26] McCullough R, Jones L, Crosby G. An analysis of the vibrational spectrum of the tetracyanonickelate(II) ion in a crystal lattice. Spectrochim Acta 1960; 16: 929-944.

[27] Sharpe AG. The chemistry of cyano complexes of the transition metals: Academic Press London; 1976.

[28] Kazuo N. Infrared and Raman spectra of inorganic and coordination compounds. New York: John Wiley and Sons. 1986; 1: 978-226.

[29] Ouyang L. The use of Tetracyanozincate(II) in the preparation of supramolecular coordination polymers: Department of Chemistry-Simon Fraser University; 2007.

[30] Nakamoto K. Infrared and Raman spectra of inorganic and coordination compounds. Part B., Applications in coordination, organometallic, and bioinorganic chemistry. 6th ed. John Wiley\&Sons, Hoboken, New Jersey, 2009.

[31] Kartal Z. Synthesis, spectroscopic, thermal and structural properties of [M(3-aminopyridine $)_{2} \mathrm{Ni}(\mu-$ $\left.\mathrm{CN})_{2}(\mathrm{CN})_{2}\right]_{n}(\mathrm{M}(\mathrm{II})=\mathrm{Co}$ and $\mathrm{Cu})$ heteropolynuclear cyano-bridged complexes. Spectrochim Acta Part A. 2016; 152: 577-583.

[32] Kürkçüoğlu GS, Sayın E, Şahin O. Cyanide bridged hetero-metallic polymeric complexes: Syntheses, vibrational spectra, thermal analyses and crystal structures of complexes $\left[\mathrm{M}(1,2-\mathrm{dmi})_{2}\right.$ $\left.\mathrm{Ni}(\mu-\mathrm{CN})_{4}\right]_{\mathrm{n}}(\mathrm{M}=\mathrm{Zn}$ (II) and Cd (II)). J Mol Struct. 2015; 1101: 82-90.

[33] Kürkçüoğlu GS, Gör K, Büyükgüngör O. New cyano bridged heteropolynuclear $\mathrm{Cu}(\mathrm{II})$ and Cd(II)tetracyanopalladate(II) polymeric complexes with 2-methylimidazole ligand. Spectrochim Acta A. 2014; 124: 588-594. 